\title{
すべり軸受ロータ系の安定限界の簡易予測
}

関口 泰久 ${ }^{* 1}$, 松田 隆太郎 ${ }^{* 2}$, 大上 雅弘 ${ }^{* 3}$, 松下 修己 ${ }^{* 4}$

\section{Simplified prediction of stability limit for oil film bearing rotor systems}

\author{
Yasuhisa SEKIGUCHI ${ }^{* 1}$, Ryutaro MATSUDA ${ }^{* 2}$, Masahiro OKAMI ${ }^{* 3}$ and Osami MATSUSHITA ${ }^{* 4}$ \\ ${ }^{* 1}$ Mechanical Systems Engineering, Graduate School of Engineering, Hiroshima University \\ 1-4-1 Kagamiyama, Higashi-Hiroshima-shi, Hiroshima 739-8527, Japan \\ ${ }^{* 2, * 3}$ Graduate School of Engineering, Hiroshima University \\ 1-4-1 Kagamiyama, Higashi-Hiroshima-shi, Hiroshima 739-8527, Japan \\ ${ }^{*}$ Department of Mechanical Engineering, National Defense Academy \\ 1-10-20 Hashirimizu, Yokosuka-shi, Kanagawa 239-8686, Japan
}

Received: 16 November 2018; Revised: 13 May 2019; Accepted: 12 April 2020

\begin{abstract}
Oil film bearings are often used in large rotating machinery because they have large load capacity and damping coefficients. They, however, generate fluid forces and cause unstable vibrations such as oil whirl and oil whip at high rotational speed. Because the amplitudes of such self-excited vibrations are severe, it is important to predict the stability limit of rotational speed to avoid the unstable vibration problems in rotor systems supported by oil film bearings. This paper describes the vibration analyses of a flexible rotor system supported by oil film bearings and the simplified prediction method for the rotational speed limits of the self-excited vibration induced by the fluid force in oil film bearings. In the vibration analyses, the equations of motion for the rotor system are simplified and modeled as a two-degree-of-freedom system with parallel and flexural modes of vibration. The stability analyses are conducted by introducing the approximation equations instead of complex eigenvalue calculations. The rotational speed limits for the stability of the system obtained by the present method are compared with the calculation results in the references to discuss the validity of the present method. This paper also shows the importance of anisotropic properties of oil film bearings to increase the accuracy of stability prediction when the clearance of the oil film bearing is large.
\end{abstract}

Keywords : Flexible rotor, Oil film bearing, Oil whirl, Oil whip, Instability prediction, Rotational speed limit

\section{1. 緒言}

大型回転機械の軸受部には，減衰効果を有し，振動抑制効果の高い寸べり軸受が用いられることが多い。しか しながらすべり軸受が不安定化力を発生し，オイルホワールやオイルホイップと呼ばれる自励振動の原因となる ことがある．その際の振動振幅は過大となるため，機械の設計段階においてロータ系の振動解析を行い，安定限 界となる回転数を把握しておき, 不安定振動の発生を防ぐことは大切である.安定限界の詳細な解析においては, 1 D-FEM（有限要素法）（松下，2018）や伝達マトリックス法 (菊地，小林，1977，Kikuchi and Kobayashi，1977) を使用し，ばねおよび咸衰に関する 8 パラメータといわれるすべり軸受動特性（松下他，2012）などを加味し， 複素固有值計算を行い，減衰比（Q值）あるいは安定性の判別が行われている.

しかし，一般に複素固有值の計算は困難であるが，安定限界を見つけることに限定すれば，簡易的にそれを求 めることは可能であると考える．またとれに特化した理解は，安定限界の物理的な解釈に有用である.

No.18-00460 [DOI:10.1299/transjsme.18-00460], J-STAGE Advance Publication date : 20 April, 2020

本論文は，Dynamics and Design Conference 2018 講演論文集(2018), No.424 の掲載内容に基づいた論文である.

${ }^{* 1}$ 正員, 広島大学大学院工学研究科機械システム工学専攻（干739-8527 広島県東広島市鏡山 1-4-1）

*2 広島大学大学院工学研究科機械システム工学専攻

*3 学生員, 広島大学大学院工学研究科機械システム工学専攻

*4 正員, フェロー, 防衛大学校機械工学科（广239-8686 神奈川県横須賀市走水 1-10-20）

E-mail of corresponding author: sekiguch@hiroshima-u.ac.jp 
本論文では，すべり軸受で支持された弾性ロータの振動解析と，軸受に発生する不安定化力が原因となって発 生する自励振動の発生回転数の簡易予測法について議論する，振動解析においては，運動方程式中でロータ系の たわみ振動を平行モードと曲げモードの 2 自由度系からなるモデルで簡略化する．複素固有值解析に代わるもの として系の安定性の予測近似式を導出し, ロータの安定判別を行う. また, 本簡易予測計算によって求めた不安 定振動が発生する安定限界回転数について, 文献 (菊地, 小林, 1997, Kikuchi and Kobayashi, 1977, 松下他, 2009) に記載のあるより詳細な 1 D-FEM モデルを用いた厳密な複素固有値計算結果と比較検討し, 本簡易予測法の有用 性を示す.

\section{2. 理論解析}

\section{$2 \cdot 1$ 用体ロータ (1 自由度系) と簡易安定判別}

図 1 に示す左右対称剛体ロータの平行モードを考える. すべり軸受の動特性は Bently-Muszynska (B-M) モデル (Muszynska, 1986, 2005, Bently and Hatch, 2002) で定義し, 等方性軸受動特性 $\left(k_{d} \equiv k_{x x}=k_{y y}, c_{d} \equiv c_{x x}=c_{y y}\right.$, $k_{c} \equiv k_{x y}=-k_{y x}, c_{x y}$ および $c_{y x}$ は無視）を考える. $k_{d}, c_{d}, k_{c}$ は等方性軸受のばね, 減衰定数, クロスばねとし， $k_{c}=\lambda \Omega c_{d}$ となる $\lambda$ を定義する. 付録に示すように, ラプラス変換を用いて軸受動特性は $B R G \equiv k_{d}-j k_{c}+c_{d} s=$ $k_{d}+c_{d}(s-j \lambda \Omega)$ と表される. このようにクロスばねを入で置き換えて油膜動特性を表せ得るとするのが B-M モ デルである，ロータ全質量を $m_{t}$ として，等方性軸受の運動方程式は次式で表される.

$$
m_{t} \ddot{z}+k_{d} z+c_{d}(\dot{z}-j \lambda \Omega z)=0
$$

この式を質量 $m_{t}$ で割り，簡略化した次式を扱う。

$$
\ddot{z}+2 \zeta_{d} \omega_{d}(\dot{z}-j \lambda \Omega z)+\omega_{d}^{2} z=0
$$

ただし， $\omega_{d}^{2}=k_{d} / m_{t}, 2 \zeta_{d} \omega_{d}=c_{d} / m_{t}$ である. 式(2)の特性方程式は次式となる.

$$
s^{2}+2 \zeta_{d} \omega_{d}(s-j \lambda \Omega)+\omega_{d}^{2}=0
$$

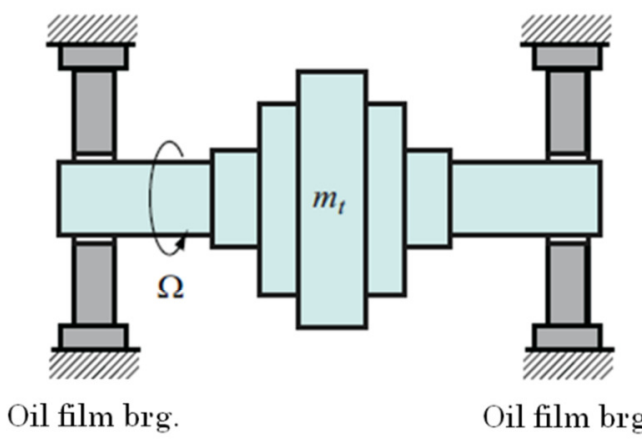
(a) Rigid rotor
(b) Single-dof

Fig. 1 Rigid rotor supported by oil film bearings.

式(3)において, パラメータ $\zeta_{d}$ が 1 より十分小さいときには特性方程式は第 2 項が無視でき, $s^{2}+\omega_{d}^{2}=0$ に近似 される. つまり特性根 $s \approx j \omega_{d}$ である. 一方， 1 より十分大きいときには（松下他，2012），特性方程式(3)を解 の公式を用いて $s$ について解き， $\zeta_{d}$ が 1 より大きいことを考慮することで，特性根は $s \approx j \lambda \Omega$ と近似できる. 不安定振動の発生寸るすべり軸受ロータ系では多くの場合, 後者である.ここではこれらの近似解のより正確な 解を求め, 安定判別を試みる.

（1） $\zeta_{d}<<1$ の場合, 改めて近似解を $s=j \omega_{d}+\Delta$ とおき, 式(3)に代入寸る. そして, $\zeta_{d}$ と $\Delta$ は微小量であ ることに注目し，2次以上の微小量を無視すると以下の結果を得る. 


$$
\begin{aligned}
& \left(j \omega_{d}+\Delta\right)^{2}+\omega_{d}^{2}+2 \zeta_{d} \omega_{d}\left(j \omega_{d}+\Delta-j \lambda \Omega\right)=0 \\
& \rightarrow 2 j \omega_{d} \Delta+2 j \zeta_{d} \omega_{d}\left(\omega_{d}-\lambda \Omega\right)=0
\end{aligned} \rightarrow \Delta=-\zeta_{d}\left(\omega_{d}-\lambda \Omega\right)
$$

（2） $\zeta_{d} \gg 1$ の場合，改めて近似解を $s=j \lambda \Omega+\Delta$ とおき，式(3)に代入し， $\zeta_{d}$ は大， $\Delta$ は微小に注目し， 2 次以上の微小量を無視すると同時に安定限界の議論故実部に着目寸ると以下の結果を得る.

$$
\begin{aligned}
& (j \lambda \Omega+\Delta)^{2}+2 \zeta_{d} \omega_{d} \Delta+\omega_{d}^{2}=0 \\
& \rightarrow \omega_{d}^{2}-(\lambda \Omega)^{2}+2 \Delta\left(j \lambda \Omega+\zeta_{d} \omega_{d}\right)=0
\end{aligned} \rightarrow \operatorname{Re}[\Delta]=-\frac{\zeta_{d} \omega_{d}\left\{\omega_{d}^{2}-(\lambda \Omega)^{2}\right\}}{2\left\{\left(\zeta_{d} \omega_{d}\right)^{2}+(\lambda \Omega)^{2}\right\}}
$$

いずれの場合も，固有值の修正分 $\Delta$ の実部は安定性に影響し，実部が 0 の場合が安定限界の回転数 $\lambda \Omega=\omega_{d}$ を示 寸.したがって回転速度が不安定の発生速度 $\Omega=\omega_{d} / \lambda$ に達し，周波数が $\omega_{d}$ の不安定振動の発生に注意する必 要がある.

すべり軸受で支持された剛体ロータ系で，固有振動数を $\omega_{d}=1$ と基準化し，パラメータ $\zeta_{d}$ 種々に変化させた ときの特性根 $s$ を求めた。特性根の実部と虚部を図 2(a)に示し，図中の実部 $\operatorname{Re}[s]$ が負から正に切り替わる回転速 度が安定限界である，虚部 $\operatorname{Im}[s]$ （減衰固有振動数）に安定根なら○，不安定根なら×を付記した．その結果○か ら×に切りかわるパラメータ $\zeta_{d}=1$ を境に, $\zeta_{d} \ll 1$ なら水平の $\bigcirc \times$ 線で,$\zeta_{d} \gg 1$ なら斜め線 $\lambda \Omega$ に $\bigcirc$ 線が沿う. 安定限界はいずれの場合も $\lambda \Omega=\omega_{d}$ の時で, この振動数において自励振動が発生する. 同図(b)は特性根 $s$ の根軌 跡であり，パラメータ $\zeta_{d}=1$ を境に $s=j \omega_{d}+\Delta$ 根と $s=j \lambda \Omega+\Delta$ 根に分かれることがわかる. 実部 $=0$ が安定 限界で， 1 自由度系の場合には $s=\left(0, \omega_{d}\right)$ が常に安定限界に一致する.

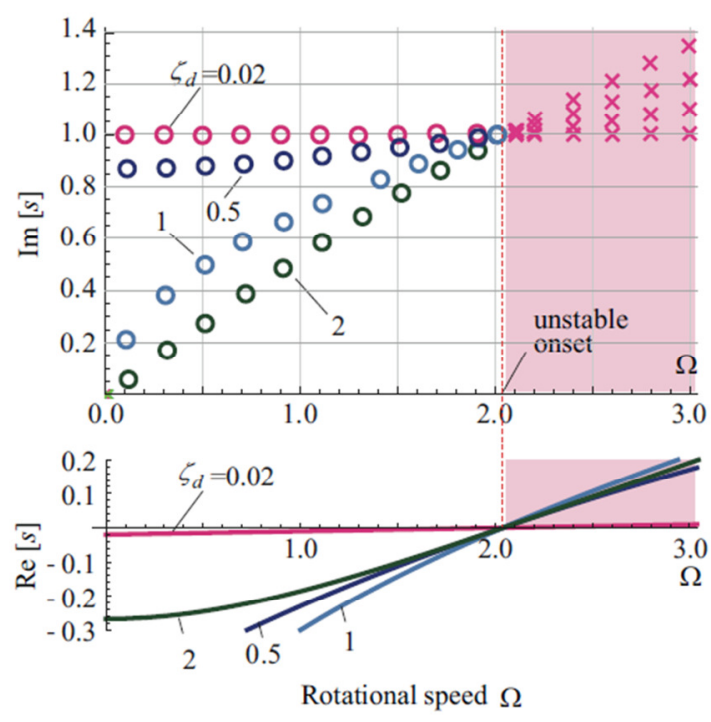

(a) $\operatorname{Re}[s]$ and $\operatorname{Im}[s]$

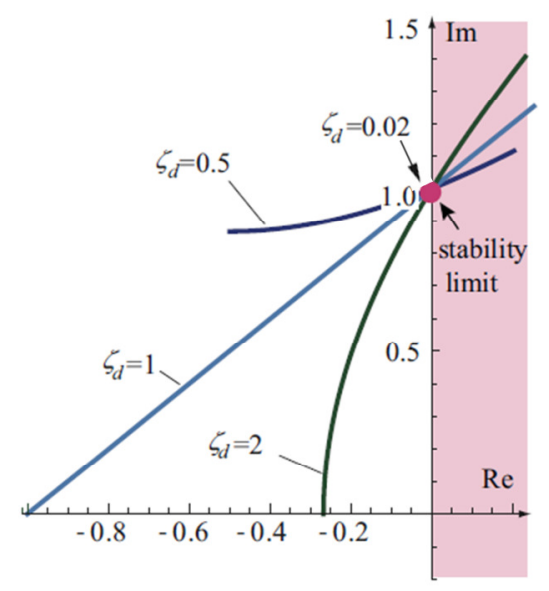

(b) Root loci of $s$

Fig. 2 Eigen frequency and Stability (1-dof $m=1, k_{d}=\omega_{d}^{2}, c=2 \zeta_{d} \omega_{\mathrm{d}}$ ). The stability limit coincides with the rotational speed where the real part of $\operatorname{Re}[s]$ changes its sign from negative to positive.

\section{$2 \cdot 2$ 弾性ロータ（2 自由度系）と不減衰固有振動数}

松下らの文献（松下他，2009）に示寸ように，図3(a)の左右対称の弾性ロータ系（全質量 $m_{t}$, 軸剛性 $k_{z}$ ) に対 して, 平行モード $\delta$ と左右の軸受部を単純支持した曲げ固有モード $\phi$ (軸固有振動数 $\omega_{2}$ ) より成るモード合成法モ デルは次式の 2 自由度系で与えられる.

$$
\left[\begin{array}{cc}
m_{t} & m_{c} \\
m_{c} & m^{*} \rightarrow 1
\end{array}\right]\left[\begin{array}{l}
\ddot{z}_{1} \\
\ddot{\eta}_{2}
\end{array}\right]+\left[\begin{array}{cc}
B R G & 0 \\
0 & k^{*} \rightarrow \omega_{z}^{2}
\end{array}\right]\left[\begin{array}{l}
z_{1} \\
\eta_{2}
\end{array}\right]=0
$$


ただし, 質量行列 $M$, 軸剛性行列 $K$, 平行モード $\mathbf{1}=[1,1, \cdots, 1]^{t}$ に対して, $m_{t}=\mathbf{1}^{t} M \mathbf{1}=$ 全質量, $m_{c}=\mathbf{1}^{t} M \phi$ $=$ 連成質量, $m^{*}=\phi^{t} M \phi \rightarrow 1=$ モード質量, $k^{*}=m^{*} \omega_{z}^{2} \rightarrow \omega_{z}^{2}$ と置いている. 軸の曲りを示す $\eta_{2}$ は相対座 標であるので, 連成質量 $m_{c}$ が存在する. 固有モードфは質量で規格化されている.

左右非対称ロータでも式(6)の形には書くことができるので, 本研究は適用できる (松下他, 2009, 伊藤他, 2007). しかし，ここではモード合成法モード $\delta, \phi の$ 形状を簡単化して説明するため左右対称形と限定して説明している.

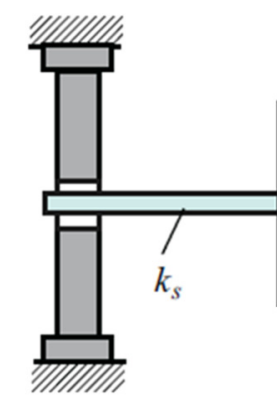

Oil film brg.

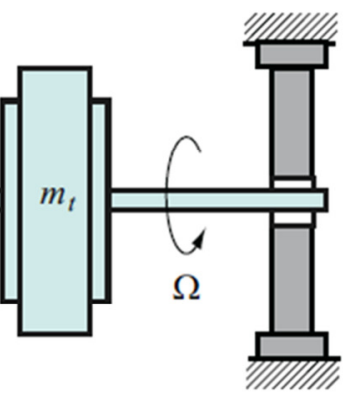

Oil film brg.

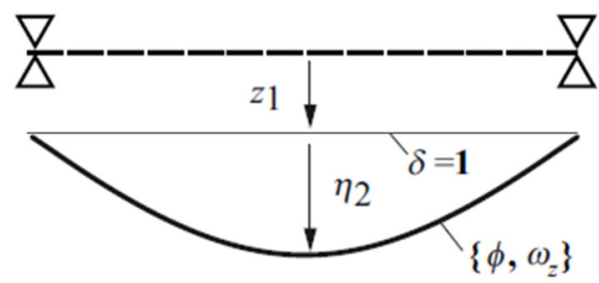

(a) Mode synthesis

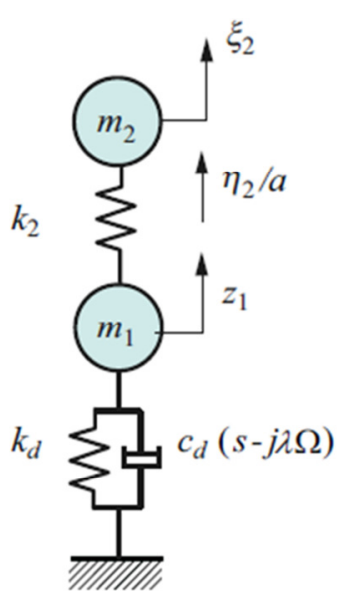

(b) Two-dof

Fig. 3 Flexible rotor supported by oil film bearings.

軸中央の円板部の絶対座標を示す量として $\xi_{2}$ を示す座標変換

$$
\eta_{2}=a\left(\xi_{2}-z_{1}\right), \quad a=m_{c} / m^{*}
$$

を定義すると，等価な 2 質点系の擬モーダルモデル（松下他，2009）が次式のように得られる.

$$
\left[\begin{array}{cc}
m_{1} & 0 \\
0 & m_{2}
\end{array}\right]\left[\begin{array}{l}
\ddot{z}_{1} \\
\ddot{\xi}_{2}
\end{array}\right]+\left[\begin{array}{cc}
B R G+k_{2} & -k_{2} \\
-k_{2} & k_{2}
\end{array}\right]\left[\begin{array}{l}
z_{1} \\
\xi_{2}
\end{array}\right]=0
$$

ただし， $m_{2}=a^{2} m^{*}$ は等価軸中央質量， $m_{1}=m_{t}-m_{2}$ は等価ジャーナル質量，および $k_{2}=m_{2} \omega_{z}^{2}$ は等価軸剛 性である. 上式を図示したものが同図(b)である. 式(6)のように $m^{*}=1$ と規格化したとき，上式で $m_{2}=a^{2}=m_{c}{ }^{2}$ であるので，連成質量とは軸中央等価質量の平方根であると言える.

ここで，モード合成法モデル式(6)に戻り，これを質量 $m_{t}$ および $m^{*}$ で規格化した変位 $z, \eta$ に次式

$$
\left[\begin{array}{l}
z_{1} \\
\eta_{2}
\end{array}\right]=\left[\begin{array}{cc}
1 / \sqrt{m_{t}} & 0 \\
0 & 1 / \sqrt{m^{*}}
\end{array}\right]\left[\begin{array}{l}
z \\
\eta
\end{array}\right]
$$

で座標変換した次式を扱う。

$$
\left[\begin{array}{cc}
1 & \mu_{c} \\
\mu_{c} & 1
\end{array}\right]\left[\begin{array}{c}
\ddot{z} \\
\ddot{\eta}
\end{array}\right]+\left[\begin{array}{cc}
\omega_{d}^{2}+2 \zeta_{d} \omega_{d}(s-j \lambda \Omega) & 0 \\
0 & \omega_{z}^{2}
\end{array}\right]\left[\begin{array}{c}
z \\
\eta
\end{array}\right]=0
$$

ただし， $\mu_{c}^{2}=m_{c}^{2} /\left(m_{t} m^{*}\right)=\left(m_{c} / m^{*}\right)^{2} m^{*} / m_{t}=m_{2} / m_{t}=$ 質量比である. その特性方程式は

$$
\left|\begin{array}{cc}
s^{2}+2 \zeta_{d} \omega_{d}(s-j \lambda \Omega)+\omega_{d}^{2} & \mu_{c} s^{2} \\
\mu_{c} s^{2} & s^{2}+\omega_{z}^{2}
\end{array}\right|=0
$$


となる．よって，減衰を無視した不減衰固有值 $s=j \omega_{n}$ は次式で得られる.

$$
D_{20}=\left|\begin{array}{cc}
-\omega_{n}^{2}+\omega_{d}^{2} & \mu_{c} \omega_{n}^{2} \\
\mu_{c} \omega_{n}^{2} & -\omega_{n}^{2}+\omega_{z}^{2}
\end{array}\right|=\left(\omega_{n}^{2}-\omega_{d}^{2}\right)\left(\omega_{n}^{2}-\omega_{z}^{2}\right)-\mu_{c}^{2} \omega_{n}^{4} \equiv y_{1}-y_{2}=0
$$

ただし， $y_{1} \equiv\left(\omega_{n}^{2}-\omega_{d}^{2}\right)\left(\omega_{n}^{2}-\omega_{z}^{2}\right) \quad y_{2} \equiv \mu_{c}^{2} \omega_{n}^{4}$ である.

$$
\text { (1) } \omega_{d}<\omega_{z}
$$

(A)

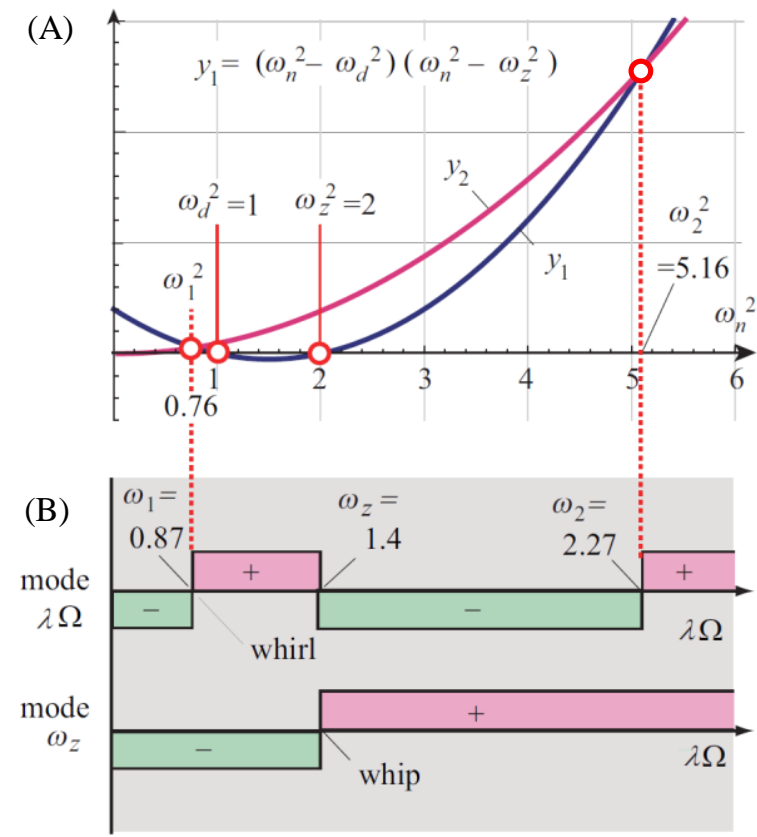

(2) $\omega_{z}<\omega_{d}$

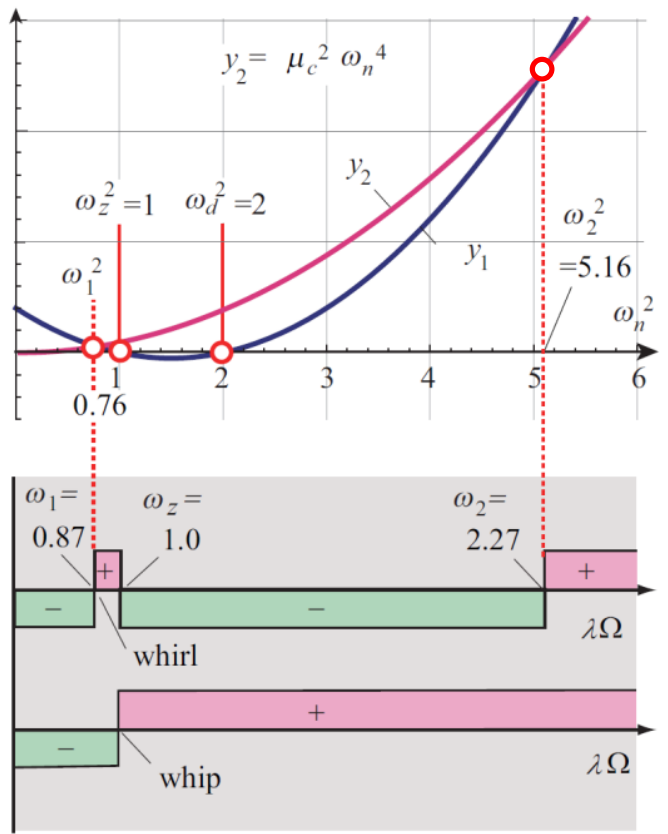

Fig. 4 Stability criteria for $\lambda \Omega$ and $\omega_{z}$ modes $\left(\zeta_{d}=\right.$ large, $\left.\mu_{c}^{2}=0.5\right)$. (A) The undamped natural frequency can be determined by the intersection between the curves $y_{1}$ and $y_{2}$. The first natural frequency $\omega_{1}$ is lower, and the second natural frequency $\omega_{2}$ is higher than both $\omega_{d}$ and $\omega_{\Sigma}$. (B) Instability occurs when $\lambda \Omega$ exceeds $\omega_{1}$, stability comes back after $\lambda \Omega$ exceeds $\omega_{z}$, and then instability occurs again when $\lambda \Omega$ exceeds $\omega_{2}$.

この図式解を図 4(A) 上部に示寸. 第 1 次および第 2 次の不減衰固有振動数 $\omega_{1}, \omega_{2}$ は $y_{1}$ と $y_{2}$ 曲線の交点である. 同図(A)(1)は $\omega_{d}<\omega_{r}$ で剛太軸の重いロータの場合，また同図(A)(2)は $\omega_{2}<\omega_{d}$ で軟細軸の軽いロータの場合である. 後者は著者らが経験した産業ポンプや圧縮機ロータのほとんどを含んでいる．いずれの場合にも，最低次固有振 動数 $\omega_{1}$ は, 剛ロー夕固有值 $\omega_{d}$ および軸曲げ固有振動数 $\omega_{2}$ のどちらの振動数より小さい. 第 2 次固有振動数 $\omega_{2}$ は それらのどちらの振動数より大きい.

なお，同下図(B)は，図 5 の説明の後に説明する.

\section{$2 \cdot 3$ 弾性ロータ (2 自由度系) の簡易安定判別}

先の 1 自由度系と同様に，次に 2 自由度系の基本解の安定性を近似的に論じる（津野田他，2016）。ここでろd 多自由度系のときの減衰比をモード減衰比の意味で略称している.

(1) $\zeta_{d}<<1$ の場合: $\zeta_{d}$ が 1 より十分小さい場合の基本解は, 不減衰固有振動数 $\omega_{1}$ と $\omega_{2}$ である. そこでまず, 第 1 次固有振動数 $\omega_{1}$ の安定性を $s=j \omega_{1}+\Delta$ で論じる.

$$
\left|\begin{array}{cc}
\left(j \omega_{1}+\Delta\right)^{2}+\omega_{d}^{2}+2 \zeta_{d} \omega_{d}\left(j \omega_{1}+\Delta-j \lambda \Omega\right) & \mu_{c}\left(j \omega_{1}+\Delta\right)^{2} \\
\mu_{c}\left(j \omega_{1}+\Delta\right)^{2} & \left(j \omega_{1}+\Delta\right)^{2}+\omega_{z}^{2}
\end{array}\right|=0
$$

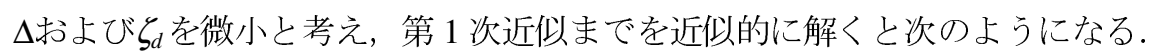




$$
\begin{aligned}
& \left|\begin{array}{cc}
-\omega_{1}^{2}+2 j \omega_{1} \Delta+\omega_{d}^{2}+2 \zeta_{d} \omega_{d}\left(j \omega_{1}-j \lambda \Omega\right) & -\mu_{c} \omega_{1}^{2}+2 j \mu_{c} \omega_{1} \Delta \\
-\mu_{c} \omega_{1}^{2}+2 j \mu_{c} \omega_{1} \Delta & -\omega_{1}^{2}+2 j \omega_{1} \Delta+\omega_{z}^{2}
\end{array}\right| \\
& =\left\{-\omega_{1}^{2}+2 j \omega_{1} \Delta+\omega_{d}^{2}+2 \zeta_{d} \omega_{d}\left(j \omega_{1}-j \lambda \Omega\right)\right\}\left(-\omega_{1}^{2}+2 j \omega_{1} \Delta+\omega_{z}^{2}\right)-\left(\mu_{c} \omega_{1}^{2}\right)^{2}+4 j \mu_{c}^{2} \omega_{1}^{3} \Delta \\
& =2 j \omega_{1} \Delta\left(\omega_{d}^{2}+\omega_{z}^{2}-2 \omega_{1}^{2}+2 \mu_{c}^{2} \omega_{1}^{2}\right)+2 j \zeta_{d} \omega_{d}\left(\omega_{1}-\lambda \Omega\right)\left(\omega_{z}^{2}-\omega_{1}^{2}\right)+\left(\omega_{z}^{2}-\omega_{1}^{2}\right)\left(\omega_{d}^{2}-\omega_{1}^{2}\right)-\mu_{c}^{2} \omega_{1}^{4}=0
\end{aligned}
$$

安定限界は上式を $\Delta$ いいて解き

$$
\Delta=-\frac{\zeta_{d} \omega_{d}\left(\omega_{1}-\lambda \Omega\right)\left(\omega_{z}^{2}-\omega_{1}^{2}\right)}{\omega_{1}\left(\omega_{d}^{2}+\omega_{z}^{2}-2 \omega_{1}^{2}+2 \mu_{c}^{2} \omega_{1}^{2}\right)}+j \frac{\left(\omega_{z}^{2}-\omega_{1}^{2}\right)\left(\omega_{d}^{2}-\omega_{1}^{2}\right)-\mu_{c}^{2} \omega_{1}^{4}}{2 \omega_{1}\left(\omega_{d}^{2}+\omega_{z}^{2}-2 \omega_{1}^{2}+2 \mu_{c}^{2} \omega_{1}^{2}\right)}
$$

その実部の正負が切り替わる振動数であるため，実部のみを考え

$$
\operatorname{Re}[\Delta]=-\frac{\zeta_{d} \omega_{d}\left(\omega_{1}-\lambda \Omega\right)\left(\omega_{z}^{2}-\omega_{1}^{2}\right)}{\omega_{1}\left(\omega_{d}^{2}+\omega_{z}^{2}-2 \omega_{1}^{2}+2 \mu_{c}^{2} \omega_{1}^{2}\right)}
$$

より, $\lambda \Omega=\omega_{1}$ となる. 同様に, 不減衰第 2 次固有振動数 $\omega_{2}$ の安定性は, $s=j \omega_{2}+\Delta$ とおいて次式となる.

$$
\operatorname{Re}[\Delta]=-\frac{\zeta_{d} \omega_{d}\left(\omega_{2}-\lambda \Omega\right)\left(\omega_{2}^{2}-\omega_{z}^{2}\right)}{\omega_{2}\left(2 \omega_{2}^{2}-\omega_{d}^{2}-\omega_{z}^{2}-2 \mu_{c}^{2} \omega_{2}^{2}\right)}
$$

よって，安定限界は $\lambda \Omega=\omega_{2}$ となる．以上より，回転数の $\lambda$ 倍の $\lambda \Omega$ が各不減衰固有振動数 $\omega_{1}, \omega_{2}$ を越えれば 不安定ということになる.

これを図示したものを図 5 上段(A)に示す. 同図(a)が $\omega_{d}<\omega_{2}$, また(b)が $\omega_{z}<\omega_{d}$ の場合である. 減衰が小さい $\zeta_{d}=0.02$ の場合, 固有振動数 $\omega_{1}$ と $\omega_{2}$ は回転数によらず一定に見える. 回転数が低いときはいずれの固有振動数も緑色で示
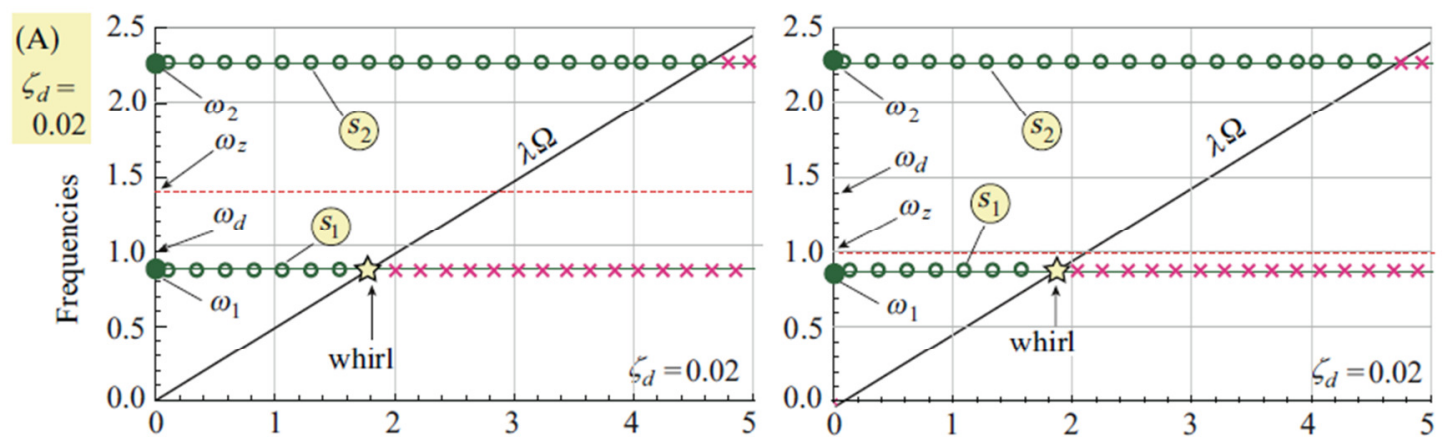

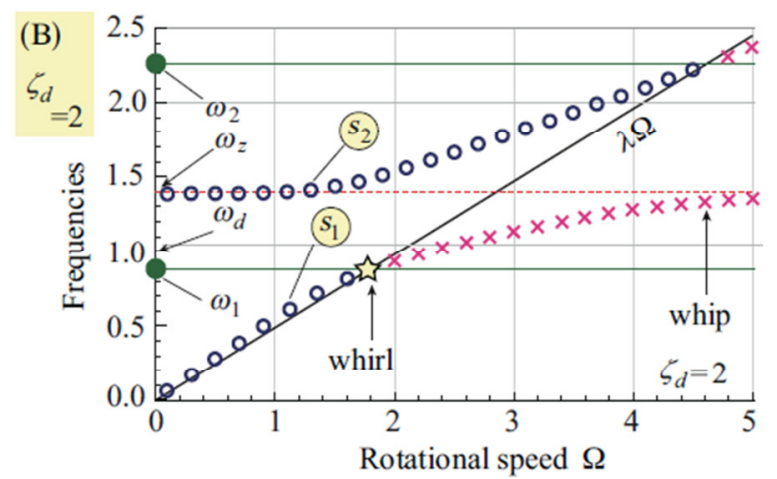

(a) Case of $\omega_{d}=1$ and $\omega_{z}=1.4$

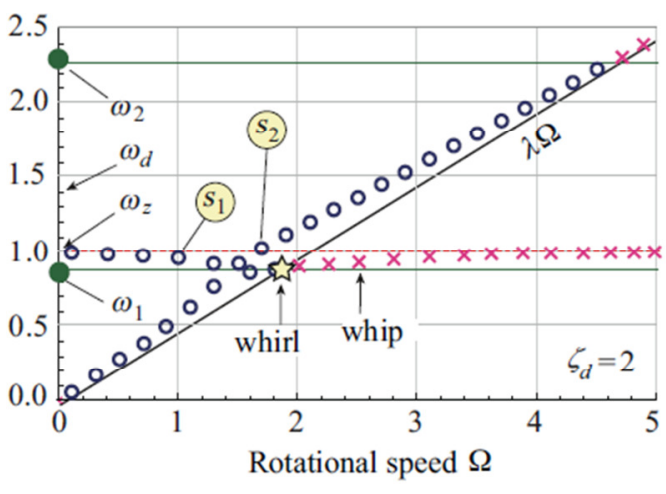

(b) Case of $\omega_{z}=1$ and $\omega_{d}=1.4$

Fig. 5 Frequency and stability $(\lambda=0.49)$. (A) When $\zeta_{d}$ is small ( 0.02$)$, both the first and second modes, $S_{1}$ and $S_{2}$, are unstable after the rotational speed exceeds $\lambda \Omega$. (B) When $\zeta_{d}$ is large (2), oil whirl instability occurs at the intersection between $\lambda \Omega$ and $\omega_{1}$, and then oil whip occurs when $\lambda \Omega$ approaches $\omega_{z}$. 
寸通り安定であるが，回転が上昇すると， $\lambda \Omega>\omega_{1}$ で○印から $\times$ 印に変化するので， 1 次モードが不安定， $\lambda \Omega>\omega_{2}$ で 2 次モードが不安定になることがわかる.

(2) $\zeta_{d} \gg 1$ の場合 : $\zeta_{d}$ が 1 より十分大きいとき，式(3)と同様の検討から式(10)は次式のように近似される.

$$
\begin{aligned}
& \left(s^{2}+2 \zeta_{d} \omega_{d}(s-j \lambda \Omega)+\omega_{d}^{2}\right)\left(s^{2}+\omega_{z}^{2}\right)-\left(\mu_{c} s^{2}\right)^{2} \\
& \approx 2 \zeta_{d} \omega_{d}(s-j \lambda \Omega)\left(s^{2}+\omega_{z}^{2}\right)=0
\end{aligned}
$$

このときの基本解は $s=j \lambda \Omega$ と $s=j \omega_{z}$ である.

そのひとつの基本解 $\lambda \Omega$ に対し，その近似解を $s=j \lambda \Omega+\Delta$ とおくと，特性方程式は次式となる.

$$
\left|\begin{array}{cc}
\omega_{d}^{2}+(j \lambda \Omega+\Delta)^{2}+2 \zeta_{d} \omega_{d} \Delta & \mu_{c}(j \lambda \Omega+\Delta)^{2} \\
\mu_{c}(j \lambda \Omega+\Delta)^{2} & (j \lambda \Omega+\Delta)^{2}+\omega_{z}^{2}
\end{array}\right|=0
$$

$\Delta$ 微小と考え，近似的に解き，以下のように置く.

$$
\begin{aligned}
& \left|\begin{array}{cc}
\omega_{d}^{2}-(\lambda \Omega)^{2} & -\mu_{c}(\lambda \Omega)^{2} \\
-\mu_{c}(\lambda \Omega)^{2} & \omega_{z}^{2}-(\lambda \Omega)^{2}
\end{array}\right|+\left|\begin{array}{cc}
2\left(\zeta_{d} \omega_{d}+j \lambda \Omega\right) \Delta & -\mu_{c}(\lambda \Omega)^{2} \\
0 & \omega_{z}^{2}-(\lambda \Omega)^{2}
\end{array}\right|+\left|\begin{array}{cc}
\omega_{d}^{2}-(\lambda \Omega)^{2} & 0 \\
-\mu_{c}(\lambda \Omega)^{2} & 2 j \lambda \Omega \Delta
\end{array}\right| \\
& =D_{20}+\Delta\left[2 \zeta_{d} \omega_{d}\left\{\omega_{z}^{2}-(\lambda \Omega)^{2}\right\}+2 j \lambda \Omega\left\{\omega_{d}^{2}+\omega_{z}^{2}-2\left(1-\mu_{c}^{2}\right)(\lambda \Omega)^{2}\right\}\right] \equiv D_{20}+\Delta(a+j b)=0
\end{aligned}
$$

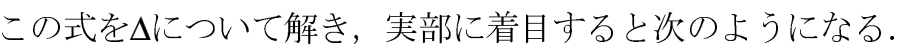

$$
\operatorname{Re}[\Delta]=\operatorname{Re}\left[-\frac{D_{20}}{a+j b}\right]=-\frac{D_{20} a}{a^{2}+b^{2}}=-\frac{2 \zeta_{d} \omega_{d}\left\{\omega_{z}^{2}-(\lambda \Omega)^{2}\right\} D_{20}}{a^{2}+b^{2}}
$$

ただし， $\omega_{1}$ と $\omega_{2}$ は不減衰系の根なので

$$
D_{20}=\left|\begin{array}{cc}
\omega_{d}^{2}-(\lambda \Omega)^{2} & -\mu_{c}(\lambda \Omega)^{2} \\
-\mu_{c}(\lambda \Omega)^{2} & \omega_{z}^{2}-(\lambda \Omega)^{2}
\end{array}\right|=\left[\omega_{1}^{2}-(\lambda \Omega)^{2}\right]\left[\omega_{2}^{2}-(\lambda \Omega)^{2}\right]
$$

である.

よって, 式(16)において安定性を示寸 $\Delta$ 正負の切り替え点は, 回転数の $\lambda$ 倍の $\lambda \Omega$ が, 各固有振動数 $\omega_{1}, \omega_{2}$ あるいは $\omega_{2}$ と交差する点である。これを図に描いたものが図 4 下段(B)の $\lambda \Omega$ モードである， $\lambda \Omega$ が第 1 次固有 振動数 $\omega_{1}$ を超えれば不安定が生じ，軸固有振動数 $\omega_{z}$ を超えれば安定に戻る. さらに第 2 次固有振動数 $\omega_{2}$ を超え れば再び不安定になると予測される。

もうひとつの基本解 $\omega_{z}$ に対し，その近似解を $s=j \omega_{z}+\Delta$ とおくと，特性方程式は次式となる.

$$
\left|\begin{array}{cc}
\omega_{d}^{2}+\left(j \omega_{z}+\Delta\right)^{2}+2 \zeta_{d} \omega_{d}\left(j \omega_{z}+\Delta-j \lambda \Omega\right) & \mu_{c}\left(j \omega_{z}+\Delta\right)^{2} \\
\mu_{c}\left(j \omega_{z}+\Delta\right)^{2} & \omega_{z}^{2}+\left(j \omega_{z}+\Delta\right)^{2}
\end{array}\right|=0
$$

$\Delta$ を微小と考え, 近似的に解き, 以下のように置く.

$$
\begin{aligned}
& \left|\begin{array}{cc}
\omega_{d}^{2}-\omega_{z}^{2}+2\left(\zeta_{d} \omega_{d}+j \omega_{z}\right) \Delta+2 \zeta_{d} \omega_{d} j\left(\omega_{z}-\lambda \Omega\right) & \mu_{c}\left(-\omega_{z}^{2}+2 j \omega_{z} \Delta\right) \\
\mu_{c}\left(-\omega_{z}^{2}+2 j \omega_{z} \Delta\right) & 2 j \omega_{z} \Delta
\end{array}\right|=0 \\
& \Delta\left\{-4 \zeta_{d} \omega_{d}\left(\omega_{z}-\lambda \Omega\right)+2 j\left(\omega_{d}^{2}-\omega_{z}^{2}+2 \mu_{c}^{2} \omega_{z}^{2}\right)\right\}-\mu_{c}^{2} \omega_{z}^{3} \equiv \Delta\left(a^{\prime}+j b^{\prime}\right)-\mu_{c}^{2} \omega_{z}^{3}=0
\end{aligned}
$$

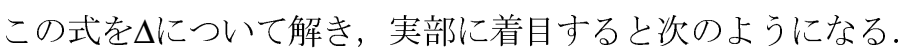

$$
\operatorname{Re}[\Delta]=\operatorname{Re}\left[\frac{\mu_{c}^{2} \omega_{z}^{3}}{a^{\prime}+j b^{\prime}}\right]=\frac{\mu_{c}^{2} \omega_{z}^{3} a^{\prime}}{a^{\prime 2}+b^{\prime 2}}=-\frac{4 \mu_{c}^{2} \zeta_{d} \omega_{d} \omega_{z}^{3}\left(\omega_{z}-\lambda \Omega\right)}{a^{\prime 2}+b^{\prime 2}}
$$


よって，安定限界は回転数の $\lambda$ 倍の $\lambda \Omega$ が軸曲げ固有振動数 $\omega_{\mathrm{L}}$ と交差する点である. これを図に描いたものが図 4(B)の $\omega_{z}$ モードである． $\lambda \Omega$ が軸曲げ固有振動数 $\omega_{L}$ を超えれば不安定が発生する.

この予測を, 実際の複素固有值計算で確認したものが図 5 に示寸 $\zeta_{d}$ が大きい場合 $\left(\zeta_{d}=2\right)$ の複素固有値虚部 (減 衰固有振動数）の曲線である. それらの減衰固有振動数曲線は低速回転域では $\lambda \Omega$ モードの右上がり線（オイル

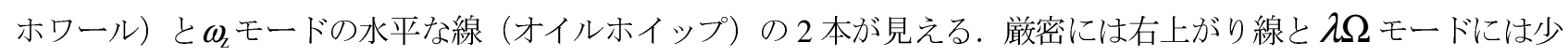
し差がある. 不安定の起点は, $\lambda \Omega$ モード曲線と第 1 次固有振動数 $\omega$ の交点にあり, 不安定根 $\lambda \Omega$ はオイルホワ 一ル現象を呈する. その後, このオイルホワールである右上がり線 $\lambda \Omega$ は, 軸曲げ固有振動数 $\omega_{\mathrm{L}}$ に接近し, 一定 值に収束し，オイルホイップ現象が生じる. 左図の(a)は長期間のオイルホワールの後にオイルホイップになる例 で，右図の(b)は直ちにオイルホイップに移る例である.

図 5 を俯瞰すると○から $\times$ に変化する安定限界は $\lambda \Omega$ である. よって回転数の上昇に伴い, 斜め線の $\lambda \Omega$ に従 えば，式(16)で示すように，最初 $\Delta$ の実部が負であることより系は安定であるが， $\lambda \Omega=\omega$ を超えると $\Delta$ の実部 が正となり不安定となる. その後 $\lambda \Omega=\omega_{z}$ で安定, $\lambda \Omega=\omega_{2}$ で再度不安定となる. また水平 $\omega_{\mathrm{L}}$ 線は式(17)のよ うに $\omega_{z}=\lambda \Omega$ を超えると $\Delta$ の実部が正となり不安定に入る. いずれにしても $\Omega>\omega_{1} / \lambda$ 少先は全域不安定であ る.

図 6 は $\zeta_{d}$ が大きい場合 $\left(\zeta_{d}=2\right)$ の根軌跡を示す. いずれの根軌跡においても, 安定限界周波数は第 1 次固有振 動数 1 であり, その際に不安定は虚軸上で生じる. また, 高速回転になると自励振動周波数は虚軸上の軸曲げ固

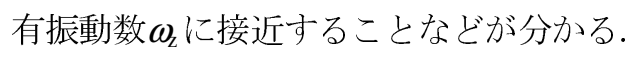

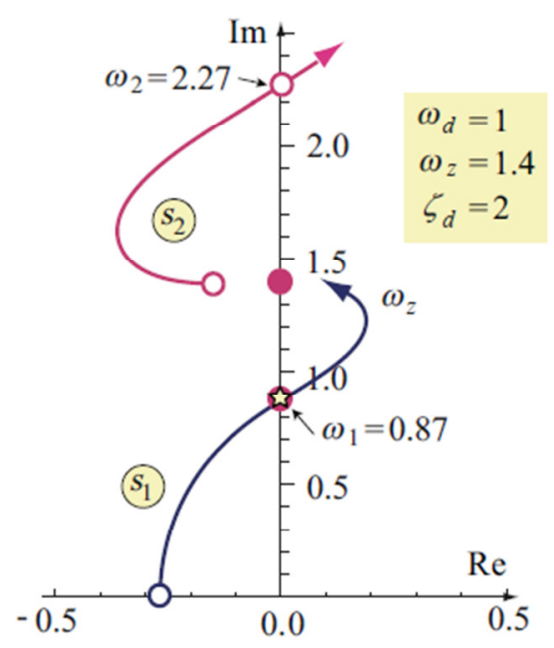

(a) Case of $\omega_{d}=1$ and $\omega_{z}=1.4$

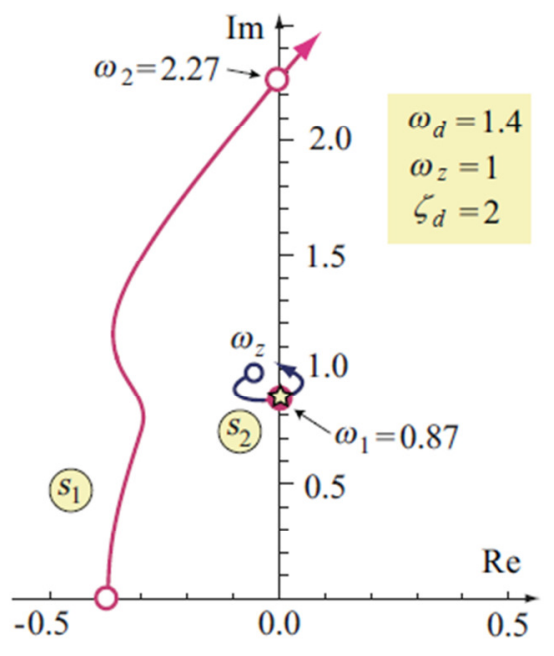

(b) Case of $\omega_{z}=1$ and $\omega_{d}=1.4$

Fig. 6 Root loci $(\lambda=0.49)$ when $\zeta_{d}$ is large (2). The stability limit exists at $\omega_{1}$. When the rotational speed is high, the frequency of self-excited vibration approaches $\omega_{z}$.

\section{2 - 43 円板を有する弾性ロータ系の計算例}

図 7 に示すロータ系に，前節に述べた手法を適用し，安定限界を予測する.

すべり軸受の動特性は回転数に依存する。しかし後述のように不安定開始速度を議論する際に重要となる回転 数は $\Omega=90 \mathrm{rps}$ である (図 9 および 11 参照).そこで本論文では簡略化のために $\Omega=90 \mathrm{rps}$ の場合の特性を採用し， すべての回転数範囲に用いることとする. 表 1 にこれらの軸受の動特性をXY 形式で示す（松下他, 2012). 次に 本計算例では表 2 のように複素数として前向き，後向きで表す.

図 7 に示寸ロータのモード解析モデルを図 8 に示寸. この 2 自由度モデルの全質量は $m_{t}=51.8 \mathrm{~kg}$, 軸曲げ固 有振動数は $\omega_{z}=47.3 \mathrm{~Hz}$, また連成質量は $\mu_{c}=0.9$ である. 図 8 に本簡易解析のための系の詳細と動特性を示寸.

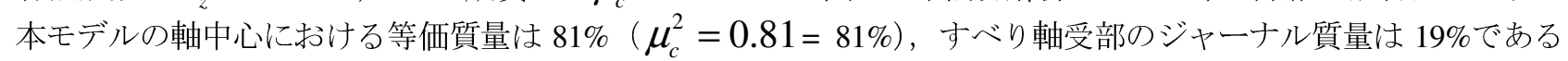
（松下他, 2009). 


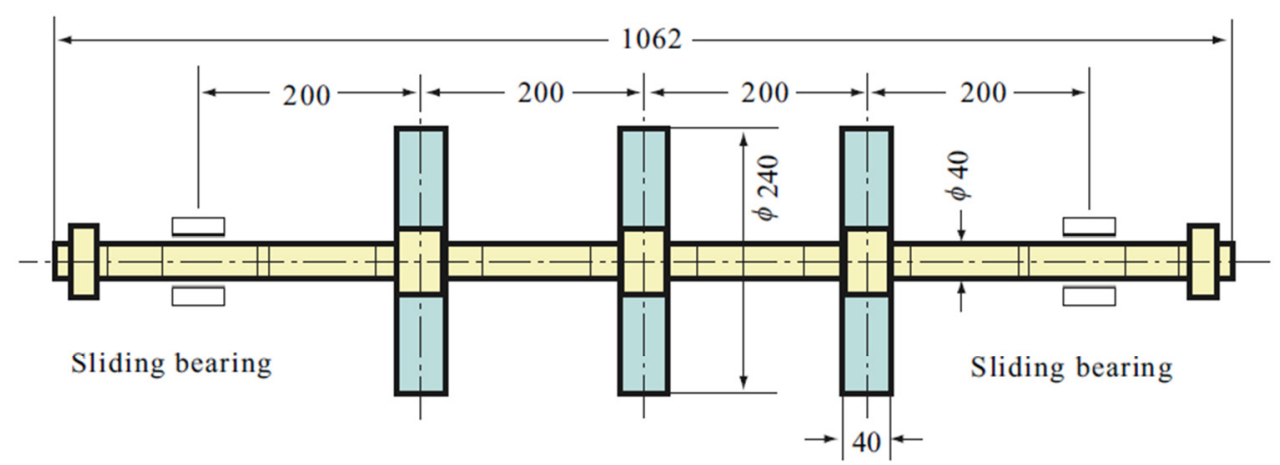

Fig. 7 Shafting system with three disks.

Table 1 Bearing dynamic properties on $x-y$ coordinates $\left(\times 10^{4} \mathrm{~N} / \mathrm{m}, \quad \times 10^{4} \mathrm{Ns} / \mathrm{m}\right)$.

\begin{tabular}{c|c|c|c|c|c|c|c|c|c}
\hline $\mathrm{C} / \mathrm{R}$ & $\Omega \mathrm{rps}$ & $k_{x x}$ & $k_{x y}$ & $k_{y y}$ & $k_{y x}$ & $c_{x x}$ & $c_{x y}$ & $c_{y y}$ & $c_{y x}$ \\
\hline 0.001 & 90 & 1,622 & 41,680 & 3,230 & $-41,438$ & 147 & 6 & 147 & 6 \\
\hline 0.003 & 90 & 669 & 2,188 & 1,042 & $-1,572$ & 7.2 & 1.8 & 6.0 & 1.8 \\
\hline 0.010 & 90 & 539 & 533 & 262 & -25 & 1.5 & 0.5 & 0.5 & 0.5 \\
\hline
\end{tabular}

表 1 は軸受ひとつ当たりの值である．問題の平行モード全体では，2 倍して次式で定義する.

$$
k_{d}=\frac{k_{x x}+k_{y y}}{2} \times 2, \quad k_{c}=\frac{k_{x y}-k_{y x}}{2} \times 2, \quad c_{d}=\frac{c_{x x}+c_{y y}}{2} \times 2, \quad \omega_{d}^{2}=\frac{k_{d}}{m_{t}}, \quad \zeta_{d}=\frac{c_{d}}{2 \omega_{d} m_{t}}, \lambda=\frac{k_{c}}{\Omega c_{d}}
$$

また，式(11)で示す $\omega_{1}$ ，および次節に示す $k_{b} ， c_{b}$ によりまとめると表 2 となる.

Table 2 Bearing dynamic modified properties $\left(\times 10^{4} \mathrm{~N} / \mathrm{m}, \times 10^{4} \mathrm{Ns} / \mathrm{m}\right)$.

\begin{tabular}{c|c|c|c|c|c|c|c|c|c}
\hline $\mathrm{C} / \mathrm{R}$ & $k_{d}$ & $k_{c}$ & $c_{d}$ & $\omega_{d} \mathrm{~Hz}$ & $\zeta_{d}$ & $\lambda$ & $\omega_{1} \mathrm{~Hz}$ & $\left|k_{b}\right|$ & $\left|c_{b}\right|$ \\
\hline 0.001 & 4,852 & 83,118 & 294 & 154 & 29.3 & 0.5 & 45.6 & 1,626 & 12.0 \\
\hline 0.003 & 1,711 & 3,760 & 13.2 & 91.4 & 2.2 & 0.503 & 42.7 & 720 & 3.79 \\
\hline 0.010 & 801 & 558 & 2.0 & 62.5 & 0.49 & 0.493 & 38.6 & 579 & 1.41 \\
\hline
\end{tabular}

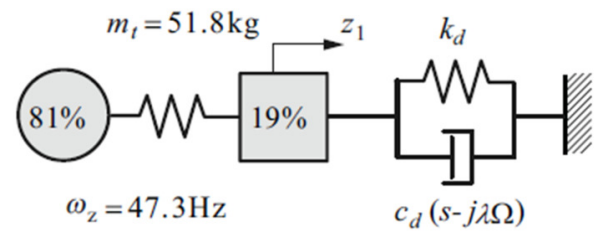

\begin{tabular}{|c|c|c|c|}
\hline $\mathrm{C} / \mathrm{R}$ & $(1) 0.001$ & $(2) 0.003$ & (3) 0.01 \\
\hline$k_{d}$ & $48 \times 10^{6}$ & $17 \times 10^{6}$ & $8 \times 10^{6}$ \\
\hline$c_{d}$ & $2.94 \times 10^{6}$ & $0.13 \times 10^{6}$ & $0.02 \times 10^{6}$ \\
\hline$\lambda$ & 0.5 & 0.503 & 0.493 \\
\hline$\zeta_{d}$ & 29.3 & 2.2 & 0.49 \\
\hline
\end{tabular}

Fig. 8 Two-dof reduced model. 
表 2 に示寸通り，式(11)により計算した図 8 の系の不減衰 1 次固有振動数は $\omega_{1}=\{45.6,42.7,38.6\} \mathrm{Hz}$ である. し たがって, 安定限界を描くと図 9 が得られる. 水平線が $\omega$ に, 右上がり線が $\lambda \Omega$ に対応している. これら両線の交 点が安定限界を示す. 不安定が生じる開始速度は $\Omega_{1}=\omega_{1} / \lambda=\{91.1,84.8,78.3\} \mathrm{rps}$ である. 軸曲げ振動数 $\omega_{2}$ は剛体 ロータを想定した固有振動数 $\omega_{d}$ より低いので，安定限界は主に低い方の振動数 $\omega_{1} \approx \omega_{z}$ で決定される.

先に述べた $\Omega=90 \mathrm{rps}$ の軸受動特性が, 全回転数域で有効であるとの仮定のもと, 悠密に複素固有值解析した 結果は, 図 9 中の右の表である. 寸なわち, 不安定開始速度 $\Omega_{1 e}=\{91.1,82.3,83.6\} \mathrm{rps}$ において不安定振動数 $\omega_{1 e}=$ $\{45.6,42.4,33.3\} \mathrm{Hz}$ が得られた. したがって係数入は $\lambda_{e}=\omega_{1 e} / \Omega_{1 e}=\{0.5,0.51,0.4\}$ となる.

不安定開始速度の予測值 $\Omega_{1}$ と厳密值 $\Omega_{1 e}$ を比較したとき, 通常の設計範囲である $\mathrm{C} / \mathrm{R}=0.001$ や $\mathrm{C} / \mathrm{R}=0.003$ のよ うに軸受の寸きま比が小さい場合には，予測值はほとんど厳密值に一致する。しかしながら， C/R=0.010におい ては，軸受動特性の異方性の影響が大きくなり，予測值と厳密值の差は無視できない大きさとなる，その際には すべり軸受動特性であるばね定数と減衰係数の後向き成分 $\left|k_{b}\right|$ および $c_{b} \mid$ 考慮し, 再度計算をする必要がある. こ の場合の計算を次節で述べる.
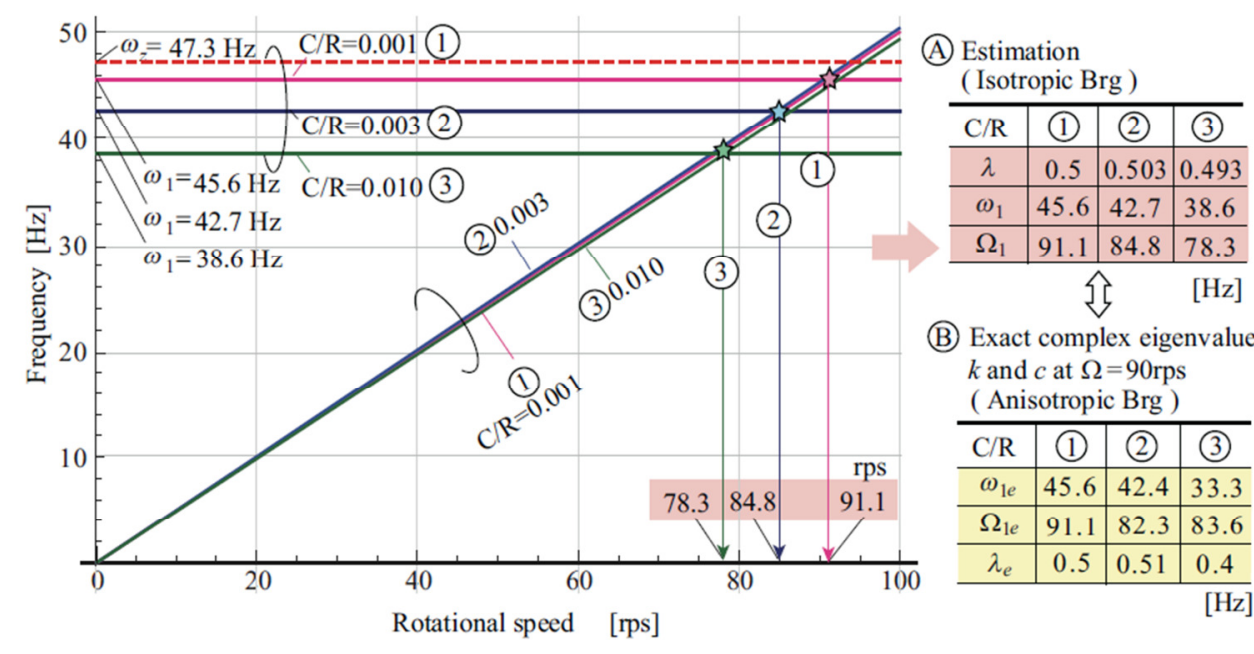

(B) Exact complex eigenvalue $k$ and $c$ at $\Omega=90 \mathrm{rps}$ (Anisotropic Brg )

\begin{tabular}{c|c|c|c}
\hline $\mathrm{C} / \mathrm{R}$ & (1) & $(2)$ & $(3)$ \\
\hline$\omega_{1 e}$ & 45.6 & 42.4 & 33.3 \\
\hline$\Omega_{1 e}$ & 91.1 & 82.3 & 83.6 \\
\hline$\lambda_{e}$ & 0.5 & 0.51 & 0.4 \\
\hline \multicolumn{4}{|c}{$[\mathrm{Hz}]$}
\end{tabular}

Fig. 9 Stability limits (Forward whirl bearing force only). The stability limit exists at the intersection between $\lambda \Omega$ and $\omega_{1}$. The estimated instability onset speed $\Omega_{1}$ coincides well with the exact speed $\Omega_{1 \mathrm{e}}$ when $\mathrm{C} / \mathrm{R}=0.001$ and 0.003 . The difference between them, however, is not negligible when $\mathrm{C} / \mathrm{R}=0.010$ because of the anisotropic characteristics of bearings.

\section{2 - 5 軸受動特性異方性の影雼}

(1) 1 自由度系

すべり軸受の動特性係数は異方性を考慮すると，ばね定数と減衰係数の前向き成分 $\left\{k_{f} c_{f}\right\}$ と後向き成分 $\left\{K_{b} . C_{b}\right\}$

$$
\begin{aligned}
& k_{f}=\frac{k_{x x}+k_{y y}}{2} \times 2-j \frac{k_{x y}-k_{y x}}{2} \times 2=k_{d}-j k_{c}, \quad K_{b}=\frac{k_{x x}-k_{y y}}{2} \times 2+j \frac{k_{x y}+k_{y x}}{2} \times 2, \\
& c_{f}=\frac{c_{x x}+c_{y y}}{2} \times 2-j \frac{c_{x y}-c_{y x}}{2} \times 2=c_{d}-j c_{c} \approx c_{d}, \quad C_{b}=\frac{c_{x x}-c_{y y}}{2} \times 2+j \frac{c_{x y}+c_{y x}}{2} \times 2
\end{aligned}
$$

を用いて，式(18)のように表せる.また，付録の式(A2)を参照して $k_{d}, c_{d}, k_{c}$ を付記している. $c_{c}$ は $c_{x y} \approx c_{y x}$ のた め省略している，等方性軸受では前者の夕で定義できるが，異方性軸受では両者を用いて表す．したがって，式 (1)に後向き成分を加え，異方性軸受動特性を有寸る 1 自由度系の運動方程式は次式となる.

$$
m_{t} \ddot{z}+k_{d} z+c_{d}(\dot{z}-j \lambda \Omega z)+K_{b} \bar{z}+C_{b} \dot{\bar{z}}=0
$$

その特性方程式は次式となる。 


$$
D_{2}=\left|\begin{array}{cc}
s^{2}+\omega_{d}^{2}+2 \zeta_{d} \omega_{d}(s-j \lambda \Omega) & k_{b}+c_{b} s \\
\bar{k}_{b}+\bar{c}_{b} s & s^{2}+\omega_{d}^{2}+2 \zeta_{d} \omega_{d}(s+j \lambda \Omega)
\end{array}\right|=0
$$

ただし $\omega_{d}^{2}=k_{d} / m_{t}, 2 \zeta_{d} \omega_{d}=c_{d} / m_{t}, k_{b}=K_{b} / m_{t}, c_{b}=C_{b} / m_{t}$ である.

式(19)を展開し，整理すると以下の式となる.

$$
\begin{aligned}
D_{2} & =\left(s^{2}+\omega_{d}^{2}\right)^{2}+\left(2 \zeta_{d} \omega_{d}\right)^{2}\left[s^{2}+(\lambda \Omega)^{2}\right]+2\left(2 \zeta_{d} \omega_{d}\right)\left(s^{2}+\omega_{d}^{2}\right) s-\left(k_{b}+c_{b} s\right)\left(\bar{k}_{b}+\bar{c}_{b} s\right) \\
& =D_{2 a}+D_{2 b} \\
D_{2 a} & \equiv\left(s^{2}+\omega_{d}^{2}\right)^{2}+\left(2 \zeta_{d} \omega_{d}\right)^{2}\left[s^{2}+(\lambda \Omega)^{2}\right]-\left(k_{b} \bar{k}_{b}+c_{b} \bar{c}_{b} s^{2}\right) \\
D_{2 b} & \equiv 2\left(2 \zeta_{d} \omega_{d}\right)\left(s^{2}+\omega_{d}^{2}\right) s-\left(k_{b} \bar{c}_{b}+\bar{k}_{b} c_{b}\right) s
\end{aligned}
$$

安定限界では， $D_{2}\left(s=j \omega_{1 a}, \omega_{1 a}=\right.$ 安定限界固有振動数）としたとき，その実部を与える $D_{2 a}(s)=0$ かつ虚 部を与える $D_{2 b}(s)=0$ となる. 虚部 $D_{2 b}(s)=0$ より安定限界時の固有振動数 $\omega_{1 a}$ を得る. それを実部 $D_{2 a}(s)$ に 代入して $D_{2 a}(s)=0$ より安定限界回転数 $\lambda \Omega$ を得る. 具体的に見てみると, 虚部 $D_{2 b}\left(s=j \omega_{1 a}\right)=0$ より, 異方 性軸受特性を有する系の安定限界時の固有振動数 $\omega_{1 a}$ が求まる.

$$
s^{2}+\omega_{d}^{2}=\frac{\operatorname{Re}\left[k_{b} \bar{c}_{b}\right]}{2 \zeta_{d} \omega_{d}} \rightarrow \omega_{1 a}^{2}=\omega_{d}^{2}-\frac{\operatorname{Re}\left[k_{b} \bar{c}_{b}\right]}{2 \zeta_{d} \omega_{d}}
$$

つまり, 不安定固有振動数 $\omega_{d}$ は, 異方性を有する系の場合には $\omega_{1 a}$ となる.

$$
\omega_{1 a}=\omega_{d} \sqrt{1-\delta_{a}} \text { ただし, } \delta_{a}=\frac{\operatorname{Re}\left[k_{b} \bar{c}_{b}\right]}{2 \zeta_{d} \omega_{d}^{3}}
$$

もし， $\delta_{a}>0$ であれば固有振動数は減少し, 逆の場合には増加する. 一方, 実部 $D_{2 a}\left(s=j \omega_{1 a}\right)=0$ より

$$
s^{2}+(\lambda \Omega)^{2}=\frac{k_{b} \bar{k}_{b}}{\left(2 \zeta_{d} \omega_{d}\right)^{2}}+\frac{c_{b} \bar{c}_{b} s^{2}}{\left(2 \zeta_{d} \omega_{d}\right)^{2}}-\frac{\operatorname{Re}\left[k_{b} \bar{c}_{b}\right]^{2}}{\left(2 \zeta_{d} \omega_{d}\right)^{4}}
$$

を得る. よって, 安定限界回転数は異方性の効果を考慮し, 次式で決まる.

$$
\lambda \Omega=\omega_{1 a} \sqrt{1+\delta_{k}-\delta_{c}-\delta_{k c}}
$$

ただし， $\delta_{k}=\frac{k_{b} \bar{k}_{b}}{\omega_{1 a}^{2}\left(2 \zeta_{d} \omega_{d}\right)^{2}}, \quad \delta_{c}=\frac{c_{b} \bar{c}_{b}}{\left(2 \zeta_{d} \omega_{d}\right)^{2}}, \quad \delta_{k c}=\frac{\operatorname{Re}^{2}\left[k_{b} \bar{c}_{b}\right]}{\omega_{1 a}^{2}\left(2 \zeta_{d} \omega_{d}\right)^{4}}$ である.

(2) 2 自由度系

運動方程式は式(6)に後向き動特性を加えて次式となる.

$$
\left[\begin{array}{ll}
m_{t} & m_{c} \\
m_{c} & m^{*}
\end{array}\right]\left[\begin{array}{c}
\ddot{z}_{1} \\
\ddot{\eta}_{2}
\end{array}\right]+\left[\begin{array}{cc}
B R G_{-} F & 0 \\
0 & k^{*}
\end{array}\right]\left[\begin{array}{l}
z_{1} \\
\eta_{2}
\end{array}\right]+\left[\begin{array}{cc}
B R G_{-} B & 0 \\
0 & 0
\end{array}\right]\left[\begin{array}{l}
\bar{z}_{1} \\
\bar{\eta}_{2}
\end{array}\right]=0
$$

ただし, $B R G_{-} F=k_{d}+c_{d}(s-j \lambda \Omega), B R G_{-} B=K_{b}+C_{b} s$

式(9)のように無次元質量行列を用いて規格化すると次式となる.

$$
\left[\begin{array}{cc}
1 & \mu_{c} \\
\mu_{c} & 1
\end{array}\right]\left[\begin{array}{l}
\ddot{z}_{11} \\
\ddot{\eta}_{21}
\end{array}\right]+\left[\begin{array}{cc}
b r g_{-} F & 0 \\
0 & \omega_{z}^{2}
\end{array}\right]\left[\begin{array}{l}
z_{11} \\
\eta_{21}
\end{array}\right]+\left[\begin{array}{cc}
b r g_{-} B & 0 \\
0 & 0
\end{array}\right]\left[\begin{array}{l}
\bar{z}_{11} \\
\bar{\eta}_{21}
\end{array}\right]=0
$$

ただし, $b r g_{-} F=\left(B R G_{-} F\right) / m_{t}=\omega_{d}^{2}+2 \zeta_{d} \omega_{d}(s-j \lambda \Omega), \quad b r g_{-} B=\left(B R G_{-} B\right) / m_{t}=k_{b}+c_{b} s$, $\omega_{z}^{2}=k^{*} / m_{t}, \quad z_{11}=\sqrt{m_{t}} z_{1}, \quad \eta_{21}=\sqrt{m^{*}} z_{1}$ である. 
よって，特性方程式は次式となる.

$$
\begin{aligned}
& \left|\begin{array}{cccc}
s^{2}+2 \zeta_{d} \omega_{d}(s-j \lambda \Omega)+\omega_{d}^{2} & \mu_{c} s^{2} & k_{b}+c_{b} s & 0 \\
\mu_{c} s^{2} & s^{2}+\omega_{z}^{2} & 0 & 0 \\
\bar{k}_{b}+\bar{c}_{b} s & 0 & s^{2}+2 \zeta_{d} \omega_{d}(s+j \lambda \Omega)+\omega_{d}^{2} & \mu_{c} s^{2} \\
0 & 0 & \mu_{c} s^{2} & s^{2}+\omega_{z}^{2}
\end{array}\right| \\
& =\left|\begin{array}{cc}
s^{2}+2 \zeta_{d} \omega_{d}(s-j \lambda \Omega)+\omega_{d}^{2} & \mu_{c} s^{2} \\
\mu_{c} s^{2} & s^{2}+\omega_{z}^{2}
\end{array}\right|\left|\begin{array}{cc}
s^{2}+2 \zeta_{d} \omega_{d}(s+j \lambda \Omega)+\omega_{d}^{2} & \mu_{c} s^{2} \\
\mu_{c} s^{2} & s^{2}+\omega_{z}^{2}
\end{array}\right| \\
& -\left(k_{b}+c_{b} s\right)\left(\bar{k}_{b}+\bar{c}_{b} s\right)\left(s^{2}+\omega_{z}^{2}\right)^{2}=0
\end{aligned}
$$

安定限界の特性根を $S=j \omega_{a}$ と表すと，上式の実部，虚部は次式で与えられる.

実部: $D_{F 0}^{2}+\left(2 \zeta_{d} \omega_{d}\right)^{2}\left(s^{2}+\omega_{z}^{2}\right)^{2}\left[s^{2}+(\lambda \Omega)^{2}\right]-\left(k_{b} \bar{k}_{b}+c_{b} \bar{c}_{b} s^{2}\right)\left(s^{2}+\omega_{z}^{2}\right)^{2}=0$

虚部: $2\left(2 \zeta_{d} \omega_{d}\right) s\left(s^{2}+\omega_{z}^{2}\right) D_{F 0}-\left(k_{b} \bar{c}_{b}+\bar{k}_{b} c_{b}\right) s\left(s^{2}+\omega_{z}^{2}\right)^{2}=0$

ただし， $D_{F 0}=\left|\begin{array}{cc}s^{2}+\omega_{d}^{2} & \mu_{c} s^{2} \\ \mu_{c} s^{2} & s^{2}+\omega_{z}^{2}\end{array}\right|=0$ は等方性軸受系の場合の 1 次不滅衰固有振動数 $\omega_{1}$ 与える.

式(29)より不安定固有振動数 $s=j \omega_{a}$ が決まる.

$$
D_{F 0}=\frac{\operatorname{Re}\left[k_{b} \bar{c}_{b}\right]}{2 \zeta_{d} \omega_{d}}\left(s^{2}+\omega_{z}^{2}\right) \rightarrow\left(s^{2}+\omega_{d}^{2}\right)\left(s^{2}+\omega_{z}^{2}\right)=\left(\mu_{c} s^{2}\right)^{2}+\delta_{a} \omega_{d}^{2}\left(s^{2}+\omega_{z}^{2}\right)
$$

この 1 次不減衰固有振動数 $\omega_{1}$ の図式解は図 10 である. 図中の曲線 $y_{1}$ と $y_{2}$ は式(11)に示すもので，両者の交点が 前向きふれまわり成分のみを有する等方性軸受系の場合の固有振動数 $\omega_{1}$ である. 前向きと後向きのふれまわり成 分を考慮した場合には，固有振動数 $\omega_{1 a}$ は，曲線 $y_{1}$ と図中の $y_{3}$ の交点となる.この振動数 $\omega_{1 a}$ は， $\omega_{1 a}<\omega_{1}$ であ るのでわずかに $\omega_{1}$ より低い，その推定近似式は前述の式(22)で表される.

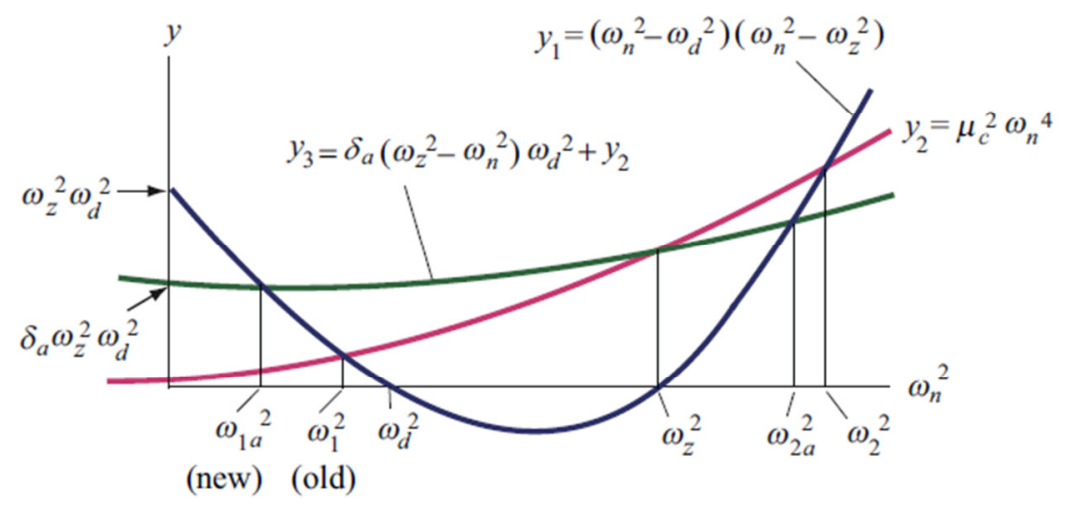

Fig. 10 Natural frequency revised by backward properties. The natural frequency can be determined by the intersection between curves $y_{1}$ and $y_{3}$, instead of $y_{1}$ and $y_{2}$ in Fig. 4 , when the anisotropic characteristics of bearings are taken into account in the calculations.

次に安定限界回転数 $\lambda \Omega$ は式(28)より次のように決まる.

$$
s^{2}+(\lambda \Omega)^{2}=\frac{k_{b} \bar{k}_{b}+c_{b} \bar{c}_{b} s^{2}}{\left(2 \zeta_{d} \omega_{d}\right)^{2}}-\frac{D_{F 0}^{2}}{\left(2 \zeta_{d} \omega_{d}\right)^{2}\left(s^{2}+\omega_{z}^{2}\right)^{2}}=\frac{k_{b} \bar{k}_{b}+c_{b} \bar{c}_{b} s^{2}}{\left(2 \zeta_{d} \omega_{d}\right)^{2}}-\frac{\operatorname{Re}^{2}\left[k_{b} \bar{c}_{b}\right]}{\left(2 \zeta_{d} \omega_{d}\right)^{4}}
$$


上式に $s=j \omega_{a}$ を代入して，安定限界回転数は以下のように計算できる.

$$
(\lambda \Omega)^{2}=\omega_{1 a}^{2}\left[1+\frac{k_{b} \bar{k}_{b}}{\omega_{1 a}^{2}\left(2 \zeta_{d} \omega_{d}\right)^{2}}-\frac{c_{b} \bar{c}_{b}}{\left(2 \zeta_{d} \omega_{d}\right)^{2}}-\frac{\operatorname{Re}^{2}\left[k_{b} \bar{c}_{b}\right]}{\omega_{1 a}^{2}\left(2 \zeta_{d} \omega_{d}\right)^{4}}\right]=\omega_{1 a}^{2}\left(1+\delta_{k}-\delta_{c}-\delta_{k c}\right)
$$

（3）計算精度の検証

等方性の軸受特性を有する場合に前向きふれまわりのみを考慮し，安定性予測を行った結果を図 9 に示した. しかしながら，軸受の寸きま比が大きい $\mathrm{C} / \mathrm{R}=0.010$ の場合には，軸受動特性の強い異方性のため，不安定開始回 転数の予測精度は十分ではなかった。ここで再度新しい式(30)より軸受動特性に異方性があり，後向きふれまわ りを扱う場合の予測精度を考察する．新しい式による $\mathrm{C} / \mathrm{R}=\{0.001,0.003,0.010\}$ の場合における計算過程を表 3 に示寸.

図 10 の図式解法により式(30)を解く前に, 表 3 の 3 行目に示寸無次元係数 $\delta_{a}$ にいては, $\mathrm{C} / \mathrm{R}=0.010$ の際には $\omega_{1}$ から $\omega_{1 a}$ への変化に伴い，比較的大きな影響があるが，それ以外の寸きま比の場合には，それほどの変化がな いことがわかる．同表 1 行目に示寸通り，等方性の場合の安定限界での振動数は $\omega_{1}=\{45.6,42.7,38.6\} \mathrm{Hz}$ である が，式(30)の解によると，異方性のある場合には，同表 4行目に示寸通り， $\omega_{1 a}=\{45.6,42.4,33.3\} \mathrm{Hz}$ となる. $\mathrm{C} / \mathrm{R}=0.010$ の場合には 38.6 から $33.3 \mathrm{~Hz}$ に低下し，安定性の上で「不利」である.

次に 5 から 10 行目において不安定の開始速度を計算した. 軸受剛性の異方性の比 $\delta_{k}$ にって安定性が向上し, 減衰異方性の比 $\delta_{c}$ にっって安定性が低下寸る，比 $\delta_{k c}$ (剛性異方性と減衰異方性の積) によって安定性に影響があ ることがわかる.これらの比の合計を同表 8 行目に示す. C/R=0.010の場合には, 式(32)中の $1+\delta_{k}-\delta_{c}-\delta_{k c}=1.53$ とな り，安定性の上で「有利」である. 9 行目に示すように，不安定開始回転数は $\Omega_{1 a}=\{91.0,82.0,83.5\}$ rps となり， 結果的に $\lambda_{a}=\omega_{1 a} / \Omega_{1 a}=\{0.50,0.51,0.40\}$ となる. 表 3 に示寸通り, $\mathrm{C} / \mathrm{R}=0.001$ および 0.003 の場合については, す きま比が十分に小さく, 異方性は無視できるので, 安定限界回転数はほぼ変わらない. しかし $\mathrm{C} / \mathrm{R}=0.010$ の場合 には，上記「有利」と「不利」の積が示寸通り，安定限界回転数が向上し，安定域が拡大寸る，いわゆる軸受剛 性の異方性で安定性が向上する.

Table 3 Parameter values influenced by backward components.

Note: $\mathrm{F}=$ only Forward whirl bearing force and

FB = both of Forward and Backward whirl bearing forces

\begin{tabular}{c|c|c|c|c|c}
\hline & \multicolumn{2}{|c|}{$\mathrm{C} / \mathrm{R}$} & 0.001 & 0.003 & 0.010 \\
\hline No. & \multicolumn{2}{|c|}{$\lambda=k_{c} /\left(c_{d} \Omega\right)$} & 0.5 & 0.503 & 0.493 \\
\hline 1 & $\mathrm{~F}$ & $\omega_{1} \mathrm{~Hz}$ & 45.6 & 42.7 & 38.6 \\
\hline 2 & $\mathrm{~F}$ & $\Omega_{1}=\omega_{1} / \lambda$ & 91 & 84.8 & 78.3 \\
\hline 3 & $\mathrm{FB}$ & $\delta_{a}$ & 0.002 & 0.08 & 0.49 \\
\hline 4 & $\mathrm{FB}$ & $\omega_{1 a} \mathrm{~Hz}$ & 45.6 & 42.4 & 33.3 \\
\hline 5 & $\mathrm{FB}$ & $\delta_{k}$ & 0.0004 & 0.042 & 1.9 \\
\hline 6 & $\mathrm{FB}$ & $-\delta_{c}$ & -0.002 & -0.08 & -0.5 \\
\hline 7 & $\mathrm{FB}$ & $-\delta_{k c}$ & 0 & -0.0014 & -0.87 \\
\hline 8 & $\mathrm{FB}$ & $\delta_{k}-\delta_{c}-\delta_{k c}$ & -0.001 & -0.042 & 0.53 \\
\hline 9 & $\mathrm{FB}$ & $\Omega_{1 a}$ onset rps & 91.0 & 82.0 & 83.5 \\
\hline 10 & $\mathrm{FB}$ & $\lambda_{a}=\omega_{1 a} / \Omega_{1 a}$ & 0.50 & 0.51 & 0.40 \\
\hline
\end{tabular}


したがって, 前向きふれまわりのみを考慮した安定性チャート図 9 を, 後向き成分を考慮して書き直すと図 11 になる. $\mathrm{C} / \mathrm{R}=0.010$ の場合には軸受特性の強い異方性のために安定限界が上昇していることがわかる. $\mathrm{C} / \mathrm{R}=0.010$ の場合には $\omega_{1 a}$ の水平線が $33.3 \mathrm{~Hz}$ 一低下寸る. しかし, 安定限界は $\Omega_{1 a}=83.5 \mathrm{rps}$ まで広がる. 同図表 C は, 交点 法による予測值をまとめた結果である。その結果は, 同図 B の厳密值に近づき，精度は向上したことが確認され る.

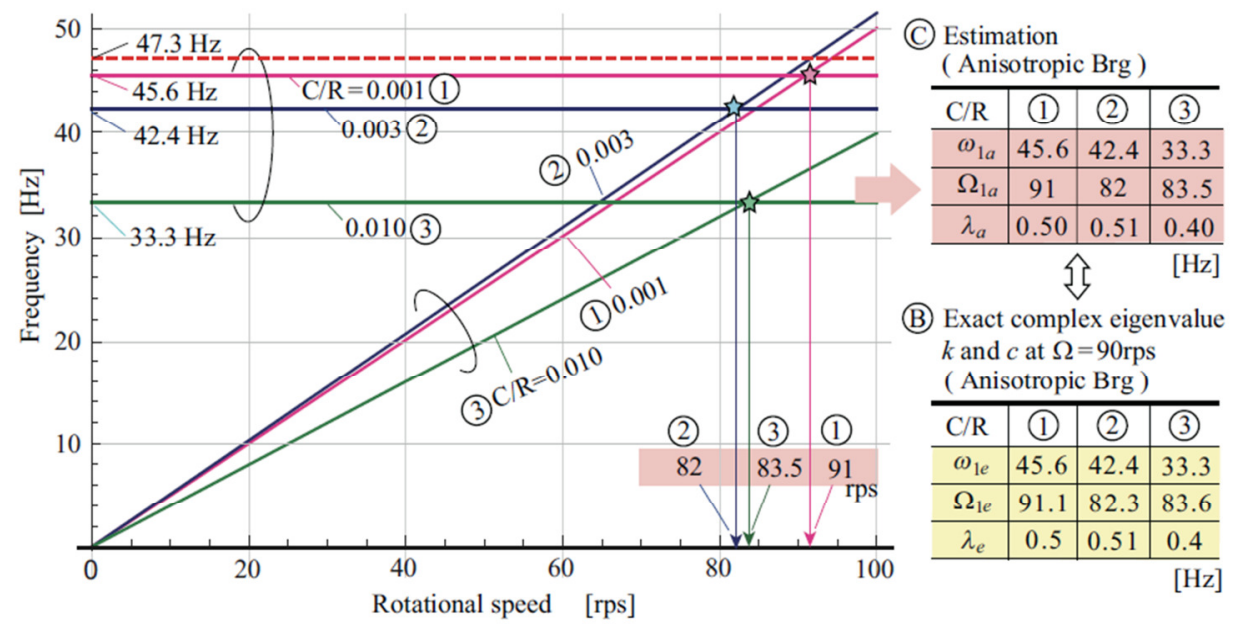

Fig. 11 Stability limit revised by backward properties. The estimated instability onset speed $\Omega_{1 a}$ calculated with the anisotropic characteristics of bearings is closer to the exact speed $\Omega_{1 e}$ compared to the calculation results in Fig. 9.

\section{3. 結 言}

本論文では，す心゙り軸受で支持された弾性ロータの振動解析と，軸受に発生する不安定化力が原因となって発 生する自励振動の発生回転数の簡易予測法について議論した。簡易予測法では, ロータ系のたわみ振動を平行モ ードと曲げモードの 2 自由度系からなるモデルで簡略化し，ロータの安定判別を行った．その結果，すべり軸受 のすきま比が実用的な範囲であれば，軸受動特性が等方的であると考え，本簡易予測計算によって精度良く安定 限界を求めることができることがわかった，また，才きま比が実用より大きい場合には，軸受動特性の異方性を 考慮した解析を行うことで，本簡易予測法の精度が向上寸ることがわかった.

\section{文}

Bently, D. E. and Hatch, C. T., Fundamentals of rotating machinery diagnostics, Bently Pressurized Bearing Press (2002). 伊藤誠, 藤原浩幸, 松下修己, 磁気軸受形オーバハングロータの Q 值評価と回転試験, 日本機械学会論文集 C 編,

Vol. 73, No. 727 (2007), pp.669-676.

菊地勝昭，小林暁峯，多軸受多円板回転軸系の安定性解析，日本機械学会論文集，Vol. 43，No. 368 (1977), pp.1338-1347.

Kikuchi, K. and Kobayashi, S., Stability analysis of a rotating shaft system with many bearings and disks, Bulletin of JSME, Vol.20, No.150 (1977), pp.1592-1600.

松下修己，田中正人，神吉博，小林正生，回転機械の振動，コロナ社 (2009), pp. 79-86, 189-192.

松下修己，田中正人，小林正生，古池治孝，神吉博，続回転機械の振動，コロナ社 (2012), pp.32, 39, 231.

松下修己, MyROT, available from <http://www.myrot.jp/>, (参照日 2018 年 11 月 10 日).

Muszynska, A., Whirl and whip rotor /bearing stability problems, Journal of Sound and Vibration, Vol.110， No.30 (1986), pp.443-462.

Muszynska, A., Rotordynamics, Chapter4, CRC Press (2005). 
染谷常雄，日本機械学会編，すべり軸受の静特性および動特性資料集，日本工業出版 (1984).

津野田亘, 土方亘, 進士忠彦, 藤原浩幸, 松下修己, 磁気軸受加振によるすべり軸受ロータの安定性診断, 日本

機械学会論文集, Vol. 82, No. 834 (2016), DOI:10.1299/transjsme.15-00500.

\section{References}

Bently, D. E. and Hatch, C. T., Fundamentals of rotating machinery diagnostics, Bently Pressurized Bearing Press (2002).

Ito, M., Fujiwara, H. and Matsushita, O., A Q-value measurement for damping evaluation and rotational test of over-hung rotor supported by AMBs, Transactions of the Japan Society of Mechanical Engineers, Series C, Vol.73, No.727 (2007), pp.669-676 (in Japanese).

Kikuchi, K. and Kobayashi, S., Stability analysis of rotating shaft system with many bearings and disks, Bulletin of JSME, Vol.43, No.368 (1977), pp.1338-1347 (in Japanese).

Kikuchi, K. and Kobayashi, S., Stability analysis of a rotating shaft system with many bearings and disks, Bulletin of the Japan Society of Mechanical Engineers, Vol.20, No.150 (1977), pp.1592-1600.

Matsushita, O., Tanaka, M., Kanki, H. and Kobayashi, M., Vibration of rotating machinery, Corona Publishing (2009), pp. 79-86, 189-192 (in Japanese).

Matsushita, O., Tanaka, M., Kobayashi, M., Koike, H. and Kanki, H., The second volume of vibration of rotating machinery, Corona Publishing (2012), pp.32, 39, 231 (in Japanese).

Matsushita, O., MyROT, available from <http://www.myrot.jp/>, (accessed on 10 November, 2018) (in Japanese).

Muszynska, A., Whirl and whip rotor /bearing stability problems, Journal of Sound and Vibration, Vol.110, No.30 (1986), pp.443-462.

Muszynska, A., Rotordynamics, Chapter 4, CRC Press (2005).

Someya, T., The Japan Society of Mechanical Engineers ed., Reference materials on static and dynamic properties of oil bearings, Japan Industrial Publishing (1984) (in Japanese).

Tsunoda, W., Hijikata, W., Shinshi, T., Fujiwara, H. and Matsushita, O., Stability diagnosis of rotor-oil film bearing system by utilizing magnetic bearing, Transactions of the JSME (in Japanese), Vol. 82, No. 834 (2016),

DOI:10.1299/transjsme.15-00500.

付

真円軸受の油膜動特性の例を文献（染谷，1984，松下他，2012）から示す．ここには無次元ばね係数 $K_{i j}$, およ び無次元粘性減衰係数 $C_{i j}$ の計 8 パラメータが示されている. 図 7 のロータ系で実機に近い $\mathrm{C} / \mathrm{R}=0.001$, 安定限 界付近の回転数 $\Omega=90 \mathrm{rps}$ のとのゾンマーフェルト数 $S$ は $3.4, S(L / D)^{2}=3.4$ であるので, 概略 $K_{x x}=1.1, K_{y y}=2.6$, $K_{x y}=-K_{y x}=30, C_{x x}=C_{y y}=60$ である. 等方性と見て, 無次元クロスばね $K_{c}=K_{x y}=30$, 無次元直交減衰 $C_{d}=60$ であ る.ここでגは有次元クロスば政 $k_{c}$ と有次元直交減衰 $c_{d} \times \Omega$ の比である. 寸なわち無次元パラメータを用い, 次の ように計算される.

$$
\lambda \equiv \frac{k_{c}}{c_{d} \Omega}=\frac{K_{c}}{C_{d}}=\frac{30}{60}=0.5
$$

このように通常運転領域では， $\lambda=$ 無次元クロスばね／無次元直交減衰はおおよそ 0.5 であることが分かる.よ って軸受動特性は, 前向き成分のみを採用し, クロス減衰は無視すると

$$
\begin{aligned}
B R G & =\frac{k_{x x}+k_{y y}}{2} \times 2-j \frac{k_{x y}-k_{y x}}{2} \times 2+\frac{c_{x x}+c_{y y}}{2} \times 2 \times s \\
& =k_{d}-j k_{c}+c_{d} s=k_{d}-j \lambda c_{d} \Omega+c_{d} s=k_{d}+c_{d}(s-j \lambda \Omega)
\end{aligned}
$$

となり，式(1)に至る. 